\title{
Cohort study of mortality of vermiculite miners exposed to tremolite
}

\author{
JC McDONALD, AD McDONALD, B ARMSTRONG, AND P SEBASTIEN \\ From the School of Occupational Health, McGill University, Montreal, Quebec, Canada
}

\begin{abstract}
A cohort of 406 men employed before 1963 for at least one year in a vermiculite mine in Montana was followed up until July 1983 . The vermiculite ore as fed to the mill contained 4-6\% of amphibole fibre in the tremolite series. Vital status was established in all but one of the 406 and death certificates were obtained and coded for 163 of the 165 men who died. Compared with white men in the United States, the cohort experienced excess mortality from all causes (SMR 1.17), respiratory cancer (SMR 2.45), non-malignant respiratory disease (SMR 2.55), and accidents (SMR $2 \cdot 14)$. Four deaths were from malignant mesothelioma (proportional mortality $2 \cdot 4 \%$ ). Compared with Montana death rates, the SMR for respiratory cancer was somewhat higher (3.03). Man-year analyses of respiratory cancer and estimated cumulative exposure gave a relation that did not depart significantly from linearity. The results of this and case-referent analyses indicate an increased risk of mortality from respiratory cancer in this cohort of about $1 \%$ for each fibre year of exposure. In relation to estimated exposure the mortality experienced by the cohort from both lung cancer and mesothelial tumours was higher than in chrysotile mining.
\end{abstract}

In April 1983 we were invited by WR Grace \& Co, owners of a vermiculite mine in Libby, Montana, to investigate the health of their employees. Morbidity and mortality studies in the same population had been initiated by NIOSH in February 1982 but, because of the urgent decisions facing them, the company wished to have an independent inquiry as quickly as possible. Having assured ourselves that NIOSH and the employees' union had no objection to parallel and complementary studies, and indeed welcomed them, our research proposals were finalised and accepted in August 1983 and we began work in September. Our studies had four components: a cohort mortality study (described in this paper), a cross sectional radiographic survey, an investigation of asbestos bodies in sputum, and an electron microscopic analysis of lung tissue samples at necropsy from ex-employees. Findings from the last three studies are reported separately, ${ }^{1-3}$ as are those of NIOSH. Although the NIOSH inquiries and our own were designed, conducted, and analysed quite separately, we discussed and compared our data and methods at every stage. This was a valuable exercise; unnecessary differences and discrepancies were elimi-

Accepted 30 September 1985 nated and the reliability of both sets of results increased.

Concern for the health of workers in this mine stemmed not from exposure to vermiculite, a micaceous mineral for which no adverse effect is suspected, but because the ore body is contaminated with fibrous amphibole deposits in the tremolite series. Fibrous tremolite and related minerals fall within the definition of asbestos ${ }^{4}$ but have limited value and are produced only in some small mines in northern Italy. On the other hand, they are common contaminants in various mining operations, notably the chrysotile mines of Quebec and certain talc mines in New York State. Other members of the amphibole family include crocidolite and amosite which cause pulmonary fibrosis, lung cancer, and malignant mesothelial tumors. Existing evidence suggests indeed that most occupationally related mesotheliomas are caused by amphibole fibres and few by chrysotile. ${ }^{5-7}$ The experience of men in the Libby mine exposed only to the tremolite group of fibres was therefore of practical concern and scientific importance.

Few observations on the effects on health of tremolite have been made. Cohort studies of employees of talc mines in New York State, some of which may contain fibrous tremolite, showed an excess of pulmonary disease and lung cancer and one or two cases of malignant mesothelioma ${ }^{89}$ In a postmortem study 
Table 1 Male deaths by age and certified cause

\begin{tabular}{|c|c|c|c|c|}
\hline \multirow[t]{2}{*}{ Cause of death (ICD code) } & \multicolumn{3}{|c|}{ Age at death (years) } & \multirow[t]{2}{*}{ Total } \\
\hline & $<45$ & $45-64$ & $\geqslant 65$ & \\
\hline \multicolumn{4}{|l|}{ Malignant neoplasms: } & $165^{*}$ \\
\hline Larynx (161) & 0 & 0 & 0 & 0 \\
\hline Trachea bronchus and lung (162) & 1 & 16 & 4 & 21 \\
\hline Pleura and mediastinum (163) & 0 & 2 & $\mathbf{0}$ & 2 \\
\hline Oesophagus and stomach $(150-1)$ & 0 & 1 & 1 & 2 \\
\hline Colon and rectum (152-3) & 0 & 2 & 0 & $\overline{2}$ \\
\hline Other abdominal (154-9) & 0 & 2 & 1 & 3 \\
\hline Other $(140-149,160,164-208)$ & 0 & 8 & 5 & 13 \\
\hline Heart disease $(390-429)$ & 1 & 21 & 32 & 54 \\
\hline Respiratory tuberculosis $(010-018)$ & 0 & 1 & 0 & 1 \\
\hline Other respiratory $(480-519)$ & 0 & 9 & 12 & 21 \\
\hline $\begin{array}{l}\text { Cerebrovascular }(430-458) \\
\text { External causes: }\end{array}$ & 0 & 4 & 7 & 11 \\
\hline \multicolumn{5}{|l|}{ External causes: } \\
\hline $\begin{array}{l}\text { Accidents (E 800-949) } \\
\text { Other (E 950-998) }\end{array}$ & 4 & 8 & 6 & 18 \\
\hline $\begin{array}{l}\text { Other (E 950-998) } \\
\text { Other causes }\end{array}$ & 2 & 2 & 1 & 5 \\
\hline $\begin{array}{l}\text { Other causes } \\
\text { Causes not known }\end{array}$ & 1 & $\begin{array}{l}3 \\
0\end{array}$ & $\begin{array}{l}5 \\
1\end{array}$ & $\begin{array}{r}10 \\
2\end{array}$ \\
\hline
\end{tabular}

*Includes four deaths from malignant mesothelioma coded ICD 163 (1), 199 (2), and 515 (1).

of 99 cases of malignant mesothelioma and matched controls four cases with more than 10 million fibres of tremolite/g dried lung were observed compared with one control. ${ }^{10}$ The comparable figures, in cases and controls, for other asbestos fibres were: chrysotile 39:33, amosite 12:1, crocidolite 9:0, and anthophyllite 2:0. In lung tissue from chrysotile miners and millers the quantity of tremolite appears similar to that of chrysotile, although only a minute fraction of the asbestos fibre mined. ${ }^{11} 12$ In a study of six cases of mesothelioma from the Quebec chrysotile mines tremolite was the predominant fibre found in the lung tissue at necropsy. ${ }^{13}$ Experimental studies in animals have shown that the carcinogenic potential of tremolite is similar to that of other fibrous amphiboles. ${ }^{14}$

Evidence of pulmonary fibrosis was first noted in an $x$ ray survey of Libby employees in 1959 and, since Grace acquired the company in 1963, employees have been examined radiographically every year. In the 1970s pulmonary function tests were added and, later, a respiratory symptom questionnaire. Intensive efforts were made to minimise exposure and a vigorous antismoking campaign was instituted to reduce the risk further. Efforts made by the company to investigate pulmonary disease among workers included the search for death certificates for all known deceased employees. Individual exposures in terms of duration and dust concentration were also estimated. An analysis of these data showed 16 lung cancers and two malignant mesotheliomas in a total of 109 deaths. This information was reported by the company to the US Environmental Protection Agency on 24 March 1983. A preliminary casecontrol analysis of these data by ourselves indicated that the lung cancer risk was probably related to cumulative exposure.

\section{Material and methods}

\section{STUDY GROUP}

Our cohort comprised all male employees with a company record of employment starting before 1 January 1963 and a net period of at least one year. These criteria were met by 406 men. Twelve were first employed before 1940 and the remainder thereafter. The vital status of each man on 1 July 1983 was sought. Inquiries were first made of relatives and friends by a recently retired long term company employee. For all those reported dead, the date and place of death were investigated; for those reported alive, the address and telephone number were requested. In cases in which these inquiries failed to produce a satisfactory result, information was submitted to drivers' licence bureaus. Finally, the results of searches of social security files for NIOSH were consulted for those men who could not otherwise be traced.

The number alive on 1 July 1983 was 226 and 165 were reported dead. A further 14 men could be traced only through social security files; these men were known to be living on 31 December 1981, but their subsequent status was not established. They were included in the man-years analysis until the date at which they were lost to view. Death certificates were sought in the state in which each of the 165 deaths was thought to have occurred and copies were obtained for 163 . The registered cause of death was coded by a single qualified nosologist according to the eighth revision of the International Classification of Diseases. Table 1 shows the causes of death.

\section{PRODUCTION PROCESS}

Vermiculite is a mineral derived from geological transformation of trioctahedral micas. ${ }^{15}$ On heating, 
the material expands about 15 times in volume and acquires useful properties. Expanded vermiculite is mainly used as an insulator against heat and noise in the construction industry and also as an absorbent low density filler and chemical carrier. Of the 325000 tons of vermiculite concentrate (before expansion) used in the United States in 1984, 54\% came from the Libby mine. According to legend, the vermiculite mountain in Libby was discovered in 1913 by Edward N Alley: walking in a short tunnel in search of metal deposit, the flame of his mining candle came in contact with vermiculite and the immediate transformation by heat attracted his attention. Commercial exploitation started in 1923 . Libby production, initially low, increased from 20000 tons in 1940 to 150000 in 1950 and 200000 in 1970.

At present mining is conducted on benches or levels that extend laterally from the surface to more than 300 vertical feet below the original surface of the mountain. Although equipment has changed over the years, ore has always been extracted by the classic technique of drilling, blasting, loading (with shovels or front end loaders), and hauling to the mill or transfer point. Drilling was considered the most dusty operation and, in 1970, nev' drills with baghouses were introduced.

After removal of coarse rock, the ore is blended and fed at controlled rates to the top of the mill. At this point the granules are about $1 \mathrm{~cm}$ in diameter and contain approximately $20 \%$ vermiculite. Accom- panying minerals are augite, biotite, calcite, diopside, hornblende, magnetite, quartz, sphene, and tremoliteactinolite. ${ }^{16}$ Milling takes advantage of differences in particle shape to separate the thin flakes of vermiculite from the blocky waste particles. The finished concentrate in 1984 contained $80-95 \%$ vermiculite. Before 1954 , the milling was basically a dry screen process. A second mill, operating a wet process, was added in 1955 to accomplish the first stages of separation. Work in the dry mill was very dusty but became much cleaner after 1965 when ventilation equipment was installed. In 1974, for hygienic and technical reasons, both dry and wet mills were shut down and ore was processed in a new mill built nearby which operated on an entirely wet process in which separation was made by vibrating screens, roll screens, Humphrey separators, and fotation. The new wet mill operates continuously, producing 1100 tons of concentrate each day in 1984; this is then dewatered, dried, and hauled to the screening plant. All the mill water is reclaimed after clarification in a tailings pond.

The screening operation separates grades of vermiculite concentrate, differing in particle size and industrial application. The techniques for handling and shipping concentrate at Libby have been changed several times with the object of controlling exposure to dust. At present most of the concentrate is shipped by rail, the loading station being equipped to reduce dust exposure; bagging is still used to a small extent.

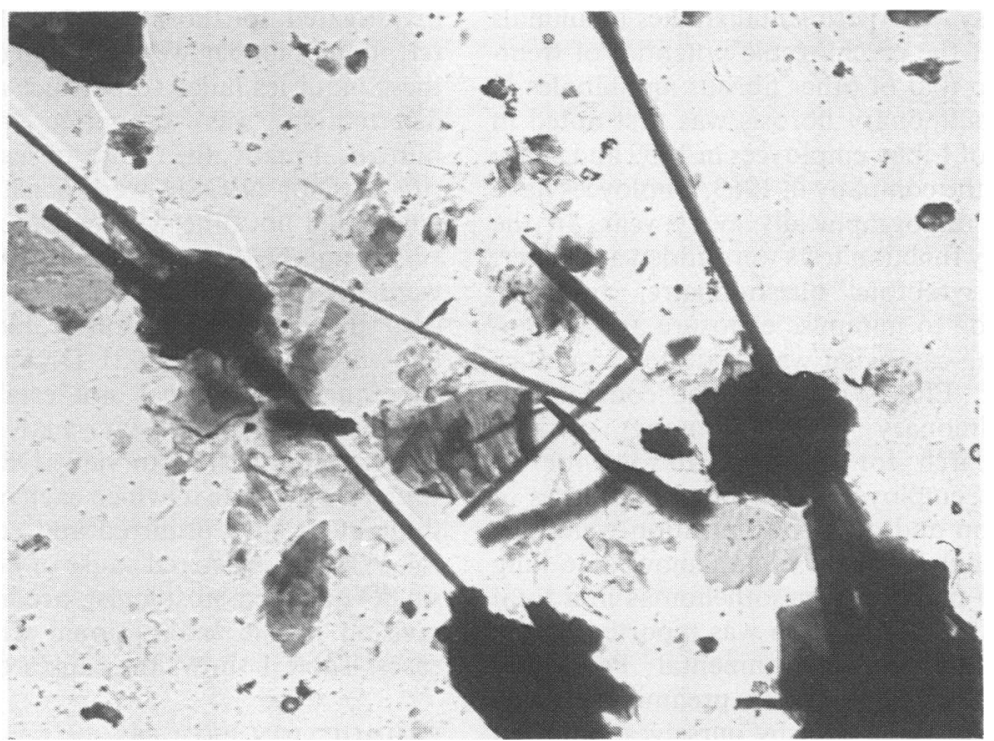

Fig 1 Dust particles and fibres collected on membrane filter in new wet mill. Transmission electron microscope view ( $1 \mathrm{~mm}=0.24 \mu \mathrm{m})$. 
MINERA LOG Y

It is well established that the vermiculite deposit in Libby is contaminated by asbestiform fibres. ${ }^{17}$ Their presence in airborne dust was first mentioned in 1956 in the report of an industrial hygiene survey by the Montana State Board of Health ${ }^{16}$ but only recently has further information become available on the nature of Libby fibres.

A systematic study by analytical transmission electron microscopy of airborne fibres collected on membrane filters in various locations of the mine and mill is now in progress. Preliminary findings on samples from the wet mill indicate that fibres exhibit several morphologies. They may be straight with uniform diameter, have a lath or needle shape, or be curved; they may be found intermingled with other platy particles (fig 1). So far, the ranges for diameter, length, and aspect ratio are $0 \cdot 1-2 \mu \mathrm{m}, 1-70 \mu \mathrm{m}$, and $3-100 \mu \mathrm{m}$ respectively. A fairly high proportion $(62 \%)$ of fibres have been found longer than $5 \mu \mathrm{m}$. Comparison of electron and optical microscope counts shows that about a third of the total airborne fibres are detected by the optical technique used for measuring exposure to asbestos at the work place. ${ }^{18}$

Elemental chemical analysis of individual fibres by energy dispersive spectrometry ${ }^{19}$ yielded unsuspected and complicated results. Although the chemistry of many fibres was compatible with minerals of the tremolite-actinolite series, the sodium content of some was too high to meet the criteria for tremolite according to the classification of the International Mineralogical Association. ${ }^{20}$ Some sodium rich fibres either displayed no calcium response (with both B sites in the theoretical formula of amphiboles occupied by sodium), and so could be called magnesioriebeckite, or displayed an intermediate calcium response (sodium distributed between $\mathrm{A}$ site and $\mathrm{B}$ site) and could be called richterite. $X$ ray diffraction analysis of Libby samples by Atkinson et al detected what they called "sodium tremolite" but it was not stated whether it was in fibrous form. ${ }^{16}$ They also observed by optical microscopy that comminution of massive amphibole crystals produced cleavage fragments resembling fibres. These observations indicate the complexity of the Libby situation; the airborne fibres are probably a mixture of different types of asbestiform and massive amphiboles. In addition, there may also be some exposure to quartz since this mineral was identified in some ore samples, ${ }^{16}$ although not reported in air samples taken in government or company surveys.

\section{EXPOSURE ESTIMATES}

Regardless of their nature, we had to estimate for each member of the cohort the cumulative fibre exposure as measured by standard optical microscope technique $^{18}$ (the so-called "regulatory fibres"). Work histories based on 42 defined job categories were obtained from the company together with detailed information on the process, its changes with time, and the introduction of control measures. Analysis of the process and observations made during two field visits (by PS) showed that the 42 job categories described the working operations with good specificity. Our general strategy for estimating cumulative exposures was (a) to take maximum advantage of existing air measurements and $(b)$ to concentrate efforts on the past dry mill period (before 1975) when substantial exposures occurred. Altogether, results of 1363 air measurements were available for the period before 1975. They were extracted from reports of surveys carried out by the company, the Montana State Board of Health, the National Center for Urban and Industrial Health, and the Bureau of Mines. Efforts to monitor the work environment that before 1967 were virtually restricted to measurements of dust concentration in the dry mill using the midget impinger method increased substantially in the 1970 s with the introduction of the membrane filter method. ${ }^{21}$ In the entire period before 1965 only 48 environmental measurements were made; this increased to 385 for the period 1965-9 and to 930 for the period 1970-4. Both static and personal sampling had been used. As most of the personal samples were short term, they probably reflected ambient concentrations rather than time weighted average exposures.

A modified version of the exposure zone concept ${ }^{22}$ was applied in using air measurements data to estimate exposure. Bearing in mind that at any time a worker is somewhere, doing something, we defined 28 operation locations (table 2). These were defined to ensure that every available air measurement could be unequivocally allocated. Information on location was used to classify static samples and that on operation to classify short term personal samples. Operation locations were further divided in periods bounded by dates of significant change in process or in control procedures. In the calculation of cumulative exposure grouped air measurements data were averaged using the technique of Oldham, ${ }^{23}$ which provides "a minimum variance unbiased estimate" of the arithmetic mean in skewed log normal distributions.

In the dry mill midget impinger measurements were made in 1944, 1956, and 1958 and much more regularly between 1962 and 1969. High dust concentrations (38.9 mpcf geometric mean) significantly dropped by a factor of about 4.6 in 1965 after the installation of a major piece of ventilation equipment, known as the scirocco fan. There was no clear indication of further consistent decrease in concentrations in the dry mill after 1965 and concentrations were taken as constant. Measurements by the mem- 
brane filter method between 1970 and 1974 showed a mean concentration of $22 \cdot 1 \mathrm{f} / \mathrm{cc}$. It was therefore assumed that the concentration in $\mathrm{f} / \mathrm{cc}$ before 1965 was 4.6 times higher-that is, $101.5 \mathrm{f} / \mathrm{cc}$. Only two operation locations were considered in the dry mill: dry mill working (except sweeping) and dry mill sweeping. Personal samples indicate that sweepers in the dry mill were exposed to concentrations about $20 \%$ higher.

For the other operation locations fibre measurements were available only for the recent periods. When the data were considered inadequate to describe past conditions, because of changes in process or control practice, arbitrary correction factors were applied. This was done after discussion with the company's representatives and especially with a previous manager who had spent almost all his career with Libby and who had extensive knowledge of the operations.

Table 2 shows the estimated average levels of exposure at the 28 operation locations from 1945 to 1982. Recent values (1957-82) were calculated in the same manner from data provided by NIOSH, where all available air measurements had been collected. As the company had introduced a systematic air sampling programme in 1975, the number of measurements for this period was much higher than in the past. As these recent measurements had been made by long term personal sampling, the operation location model may be less appropriate since the same sample may cover more than one operation location. Recent fibre counts, however, were low so it is unlikely that this materially affected the accuracy of our cumulative exposure estimates.

The work histories were available in terms of job category, not operation location. We therefore used job descriptions to estimate for each job the duration and the number of hours spent by workers in different operation locations; the cumulative exposure was then calculated. Again, the help of company representatives made this possible.

\section{STATISTICAL ANALYSIS}

The mortality of the total cohort was compared with that of white men in the United States using the person-years at risk method to compute expected numbers of deaths and hence standardised mortality ratios (SMRs). These computations were made using Monson's computer program, ${ }^{24}$ from which United States national age specific death rates, available to 1975, were also taken. Additional analyses of mortality from respiratory cancer were made using Montana death rates from published figures for numbers of deaths, together with appropriately interpolated estimates of population from censuses. Death rates for respiratory cancer for Montana were computed for the period up to 1978, and the United States national rates for this cause updated to this year for comparability.

Analysis of the relation between mortality and exposure to fibrous dust was performed in two ways. Firstly, the exposure cumulated to the end of each

Table 2 Estimated average prevailing fibre concentrations ( $\mathrm{f} / \mathrm{ml}$ ) at main work location operations $1945-82$

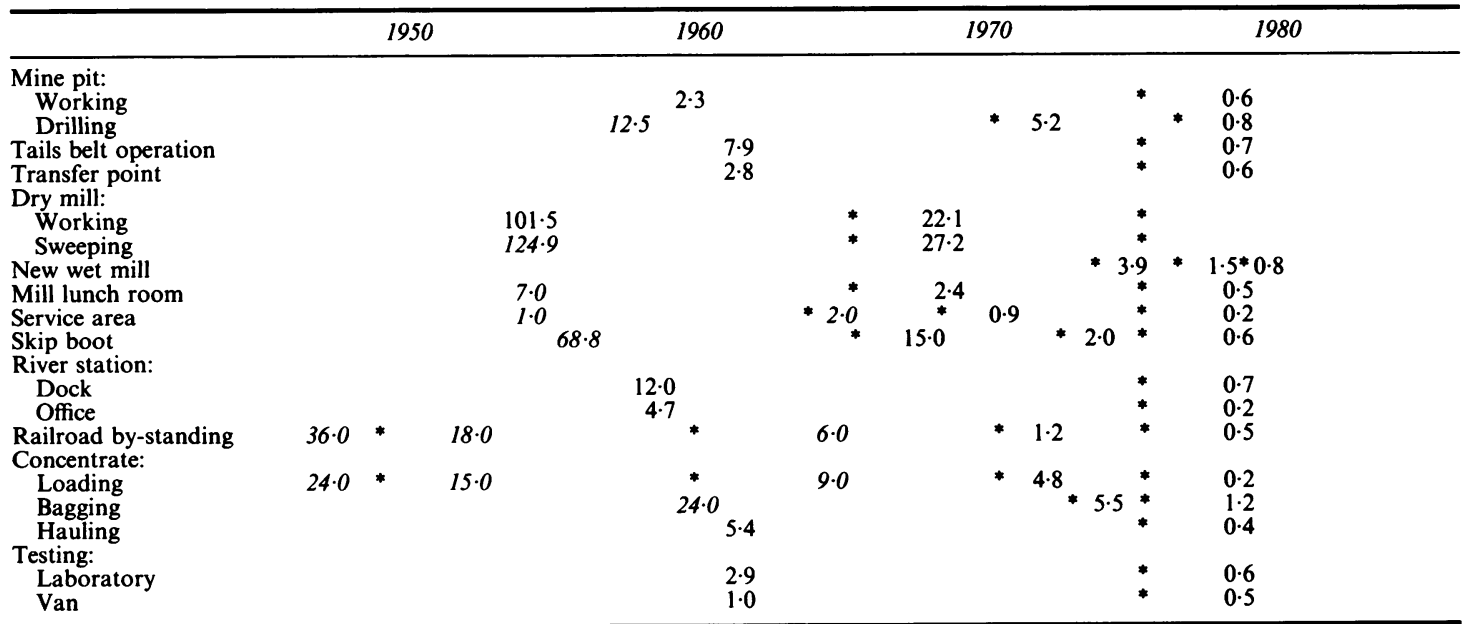

Fibre concentrations were taken as constant for the relevant periods at the following locations: bus transfer (1-2), mine lunch room $(0 \cdot 9)$, mine office $(0 \cdot 5)$, screen plant $(0 \cdot 5)$, verxite plant $(6 \cdot 0)$, office building $(<0 \cdot 04)$, hygiene laboratory $(0 \cdot 2)$, old wet mill $(5 \cdot 1)$, river station conveyor tunnel $(118 \cdot 5)$.

No measurements available for figures in italics.

*Time periods over which the estimates apply. 
Table 3 Deaths and SMRs by cause and time since first employment (reference: United States white men). (95\% Confidence intervals in parentheses)

\begin{tabular}{|c|c|c|c|c|c|c|c|c|c|}
\hline \multirow[t]{3}{*}{ Cause of death } & \multirow[t]{3}{*}{$I C D(8 t h$ rev $)$} & \multicolumn{6}{|c|}{ Time since first employment (years) } & \multicolumn{2}{|c|}{ Complete cohort } \\
\hline & & \multicolumn{2}{|c|}{$<10$} & \multicolumn{2}{|c|}{$10-19$} & \multicolumn{2}{|c|}{$\geqslant 20$} & \multirow[b]{2}{*}{0} & \multirow[b]{2}{*}{$S M R$} \\
\hline & & $\overline{0}$ & $S M R$ & $\overline{0}$ & $S M R$ & $\overline{0}$ & $S M R$ & & \\
\hline \multirow{2}{*}{$\begin{array}{l}\text { All causes } \\
\text { Malignant neoplasms: } \\
\text { Respiratory }\end{array}$} & & 17 & 0.79 & 45 & $1 \cdot 11$ & 103 & $1 \cdot 31$ & 165 & $1 \cdot 17$ \\
\hline & $160-163$ & 4 & $\begin{array}{l}5.02 \\
(1 \cdot 35-12 \cdot 85)\end{array}$ & 4 & $\begin{array}{l}1.66 \\
(0.45-4 \cdot 24)\end{array}$ & 15 & $\begin{array}{l}2.42 \\
(1.35-3.99)\end{array}$ & 23 & $2 \cdot 45$ \\
\hline $\begin{array}{l}\text { Abdominal } \\
\text { Other } \\
\text { Circulatory disease }\end{array}$ & $\begin{array}{l}150-159 \\
390-458\end{array}$ & $\begin{array}{l}1 \\
0 \\
3\end{array}$ & $\frac{0.86}{0.31}$ & $\begin{array}{r}1 \\
2 \\
20\end{array}$ & $\begin{array}{l}0.44 \\
0.69 \\
0.93\end{array}$ & $\begin{array}{r}5 \\
11 \\
42\end{array}$ & $\begin{array}{l}1.11 \\
1.83 \\
0.97\end{array}$ & $\begin{array}{r}7 \\
13 \\
65\end{array}$ & $\begin{array}{l}0.88 \\
1.26 \\
0.87\end{array}$ \\
\hline $\begin{array}{l}\text { Non-malignant: } \\
\text { Respiratory disease }\end{array}$ & & & & & & & & & \\
\hline $\begin{array}{l}\text { Respiratory disease } \\
\text { External cases: }\end{array}$ & $460-519$ & 0 & - & 7 & $3 \cdot 36$ & 14 & $5 \cdot 30$ & 21 & $2 \cdot 55$ \\
\hline $\begin{array}{l}\text { Accidents } \\
\text { Other }\end{array}$ & $\begin{array}{l}800-949 \\
950-998\end{array}$ & $\begin{array}{l}5 \\
1\end{array}$ & $\begin{array}{l}1 \cdot 80 \\
1.02\end{array}$ & $\begin{array}{l}4 \\
3\end{array}$ & $\begin{array}{l}1 \cdot 46 \\
2 \cdot 22\end{array}$ & $\begin{array}{l}9 \\
1\end{array}$ & $\begin{array}{l}3.11 \\
0.72\end{array}$ & $\begin{array}{r}18 \\
5\end{array}$ & $\begin{array}{l}2 \cdot 14 \\
1 \cdot 28\end{array}$ \\
\hline
\end{tabular}

month of each man's life, or until the end of 1982 for those who survived until then, was calculated. Person-years at risk were divided into four groups according to cumulative exposure to fibres, and expected deaths and SMRs computed for each group. A linear relation between SMR and cumulative exposure was then fitted using the GLIM program in the manner described by Hanley and Liddell. ${ }^{25}$ Secondly, relative risks were estimated from case-control sets chosen from within the cohort. Controls for each case were chosen as men surviving beyond the age of death of the case, who had been born and had started work at Libby mine within three years of the case. For each control, exposure was cumulated to the age of death of the matching case. Estimates of linear increase in relative risk (odds ratio) per unit exposure were made using the method of conditional likelihood. ${ }^{26}$

\section{Results}

The mortality experience of the cohort as a whole is summarised in table 3. Mortality for all causes was in excess of that expected for white men in the United States by 24 deaths (SMR 1-17). The SMR for all causes rose from 0.79 for the first nine years from first exposure, when "healthy worker" selection effects would be expected to be strongest, to 1.31 after 20 years from first exposure. There was a substantial excess number of deaths from respiratory cancer (SMR 2.45), from non-malignant respiratory disease (SMR 2.55), and from accidental causes (SMR 2.14). There was no evidence of an excess number of deaths from cancers of non-respiratory sites. Eight of the deaths from non-malignant respiratory disease were certified as due to pneumoconiosis (ICD 514 or 515). Of the 18 deaths due to accidental causes, five occurred while the men were employed at the mine and the other 13 after they had left. Four deaths were from mesothelioma; one coded by the nosologist to respiratory cancer (ICD 165), one to pneumoconiosis (ICD 515), and two to neoplasm without specification of site (ICD 199). Three of the cases were pleural and one peritoneal. In addition, one death was certified as due to mediastinal cancer (ICD 163) in a man nine years after first employment. At necropsy the pathol-

Table 4 Deaths from respiratory cancer (ICD 160-163), SMRs, and cumulative exposure (reference: Montana men)

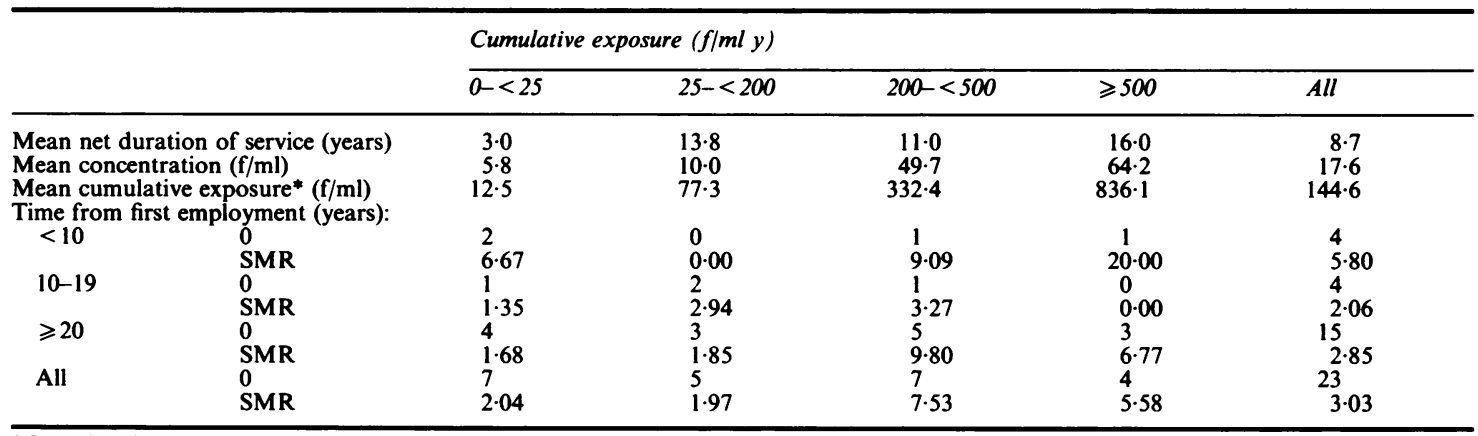

*Cumulated to end of service. 


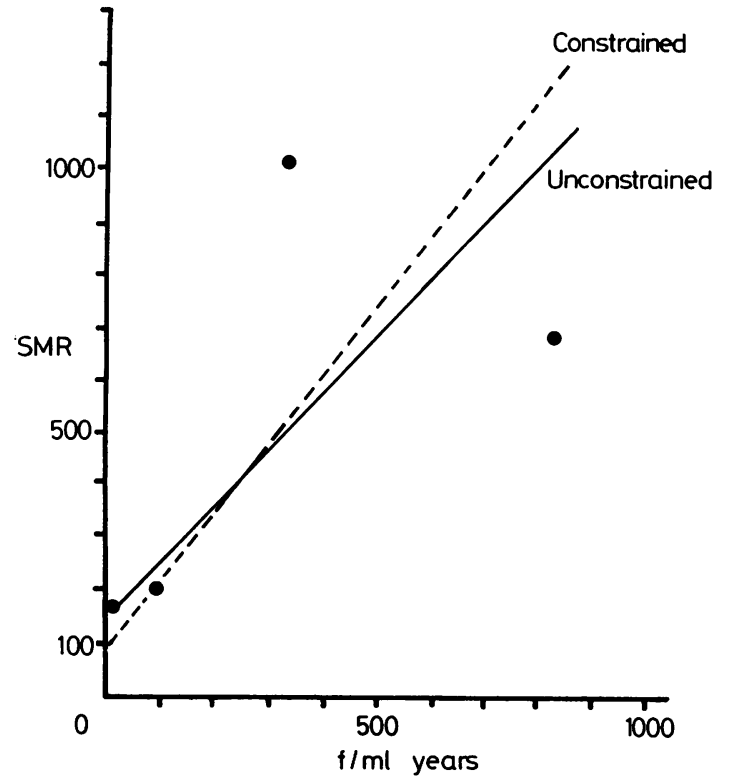

Fig 2 Respiratory cancer SMRs 20 or more years from first employment exposure ( $\mathrm{f} / \mathrm{ml}$ years).

ogist did not consider this a mesothelioma.

Using Montana death rates instead of United States national rates reduced the number of expected deaths from respiratory cancer from 9.41 to 7.60 , increasing the SMR from 2.45 to 3.03 . Table 4 gives the SMRs for respiratory cancer (using Montana death rates) by cumulative exposure. It is reasonable to focus attention on the SMRs 20 or more years from first employment, when risk due to exposure to fibres would be expected to be most evident.

A linear relation between these SMRs and cumulative exposure (see fig 2 ) is given by the equation SMR $=1.52+0.011 \mathrm{f} / \mathrm{y}$ or, expressed as a relative risk, $R R=1+0.007 \mathrm{f} / \mathrm{y}$. Alternatively, by forcing the line through $S M R=1$ at zero exposure, the equation SMR $=1.00+0.013 \mathrm{f} / \mathrm{y}$ was obtained. The observed deviation from linearity could be explained by chance $\left(\chi^{2}(3 \mathrm{df})=3.47\right)$ and the trend has high statistical significance $\left(\chi^{2}(\mathrm{ldf})=18.9, \mathrm{p}<0.001\right)$.
The constrained line may be interpreted to imply an increase in SMR for respiratory cancer of about $1.3 \%$ for each fibre year of cumulative exposure.

There is also evidence from the data in table 4 of an excess mortality from lung cancer less than 10 years from first employment. The two cases in the lowest exposure category could not have been due to work at Libby. One was a man who was first employed at age 66 and died at 69; the other joined at 25 and died at 28 . The two other deaths in the short latency category were 8.9 and 9.1 years from first employment. Both had substantial levels of cumulative exposure (470 and $522 \mathrm{f} / \mathrm{y}$ ) so a causal hypothesis is less easily dismissed.

Case-control analyses of exposure-response were carried out for the 23 deaths coded to respiratory cancer (ICD 160-163), the eight coded to pneumoconiosis (ICD 514-515), and (with some overlap) the four mesotheliomas. Results are presented in table 5. A statistically significant linear relation was found between relative risk for respiratory cancer and cumulative exposure which is clearest in cases occurring 20 or more years from first employment ( $\chi^{2}$ (ldf) $=7.04, \mathrm{p}<0.01)$. In this group the linear increase in relative risk is estimated at $1.0 \%$ per fibre year $(95 \%$ confidence interval $0 \cdot 1-9 \cdot 7)$. This relation is described by the equation $R R=1.00+0.010 \mathrm{f} / \mathrm{y}$. Although positive relations with cumulative exposure were also observed with pneumoconiosis and with mesothelioma, numbers were small, confidence intervals wide, and conventional levels of statistical significance were not reached.

\section{Discussion}

The cohort studied was not large but sufficient to show that the workers in this mine experienced a serious hazard from lung cancer, pneumoconiosis, and mesothelioma. This was presumably attributable to the fibrous amphibole contaminant of the vermiculite ore and mainly to dust conditions before 1974 , particularly in the dry mill. No precise comparison with the New York State studies can be made but the crude SMRs for lung cancer were similar, 2.4 in this study, 2.8 in the study by Kleinfeld $e t a l,{ }^{8}$ and 3.2 in that by

Table 5 Estimates of exposure: response from case-referent analysis

\begin{tabular}{|c|c|c|c|c|}
\hline Cause of death & No of cases & $\begin{array}{l}\text { Time from first } \\
\text { employment (years) }\end{array}$ & $\begin{array}{l}\beta=\% \text { increase in relative risk } \\
(O R) \text { per } f / m l \text { year }(95 \% C I)\end{array}$ & $\begin{array}{l}\chi^{2}(1 d f) \text { for } \\
H_{0}: \beta=0\end{array}$ \\
\hline $\begin{array}{l}\text { Respiratory cancer } \\
\text { (ICD 160-163) } \\
\text { Pneumoconiosis (ICD 515) } \\
\text { Mesothelioma (ICD various) }\end{array}$ & $\begin{array}{r}4 \\
4 \\
15 \\
23 \\
8 \\
4\end{array}$ & $\begin{array}{l}0-9 \\
10-19 \\
\geqslant 20 \\
\text { All } \\
\text { All } \\
\text { All }(\geqslant 20)\end{array}$ & $\begin{array}{l}2 \cdot 1(0 \cdot 0,66) \\
0 \cdot 4(-0 \cdot 1,8 \cdot 5) \\
1 \cdot 0(0 \cdot 1,9 \cdot 7) \\
0 \cdot 7(0 \cdot 1,3 \cdot 0) \\
0 \cdot 3(0 \cdot 0,4 \cdot 1) \\
0 \cdot 2(-0 \cdot 2, \geqslant 100)\end{array}$ & $\begin{array}{l}3.08 \\
1.23 \\
7.04 \\
7.49 \\
2.42 \\
0.10\end{array}$ \\
\hline
\end{tabular}


Brown et al. ${ }^{9}$ Not surprisingly, the SMR obtained in the parallel study by $\mathrm{NIOSH},{ }^{10} 2 \cdot 2$, was close to our own. In all these studies cases of mesothelioma were reported.

The findings in the NIOSH study, although close to our own, were not identical for four main reasons. (1) Their cohort was larger and included men first employed before 1969 , but observation was terminated 18 months earlier. (2) Their cohort was based on work history records, ours on computerised company work history files. Sixteen men (alive in 1981) who had started before 1963 according to the former probably more correct records had not done so according to the latter, and were thus not included in our cohort. Conversely, two men were included in the McGill cohort, although their work history records indicated that they had started in 1963. (3) Although we used the same basic exposure data, we did not treat it or interpret it in exactly the same way. (4) The same death certificates were coded by the same nosologist but with some differences. As a result of these various minor differences our risk estimates were higher than those of NIOSH.

Our analyses of respiratory cancer mortality in relation to accumulated exposure do not in themselves establish a linear relation. But, given the findings from other asbestos exposed cohorts, ${ }^{5}$ it seems reasonable to expect a similar exposure response pattern in this group also. On that assumption, our findings suggest that the observed slope (about $1 \%$ increase in lung cancer per fibre year of exposure) is the same as that calculated by Doll and Peto $^{27}$ for chrysotile textile workers. This slope was substantially steeper than that estimated for Quebec chrysotile miners and millers in whom the proportional mortality from mesothelioma was also much lower. ${ }^{28}$ Having regard for the fact that $(a)$ the Canadian miners were also exposed to tremolite fibres, albeit in low concentrations, and (b) tremolite is present at necropsy in lung tissue of these miners in similar amounts to chrysotile ${ }^{12}$ and in higher amounts in cases of mesothelioma, ${ }^{13}$ one is forced to question the relative carcinogenic potency of chrysotile even in the mines and mills where it is produced. The rarity of mesothelioma ( 1 case) in the South Carolina chrysotile textile plant where lung cancer was in great excess appears to exclude any simple explanation based solely on fibre type per se. Nevertheless, whereas the textile process, carding in particular may well separate the chrysotile bundles into finer more carcinogenic fibrils, few of which reach the pleura, amphibole fibres (including tremolite) are much less susceptible to longitudinal division but remain able to penetrate more deeply than chrysotile. For mesothelioma, penetration is the prerequisite. For lung cancer, which is initiated in the airways, as indeed is asbestosis, length, thinness, and durability of the fibrils together with tobacco smoke and perhaps other carcinogens are more important parameters than ability to penetrate.

If a linear relation between the risk of lung cancer and accumulated exposure be accepted a $1 \%$ increase in mortality per fibre year has practical implications for control in this industry. At present airborne fibre concentrations, reported by the company to average about $0 \cdot 1 \mathrm{f} / \mathrm{ml}$ the estimated risk of lung cancer over a working lifetime might be increased by about $5 \%$. This estimate, however, is associated with considerable statistical uncertainty and could vary in either direction by a factor of perhaps two or three.

From the viewpoint of epidemiological methodology, it may be worth noting that the exposure response conclusions from this study confirmed the preliminary case-control analysis of incomplete data made in 1983 mentioned in the introduction. As exposure levels had been underestimated, however, the slope of the line proved less steep than it had then appeared. Rapid analyses of this type ${ }^{29}$ deserve to be used more often for immediate assessment of occupational hazards.

This research was supported by a grant to McGill University by WR Grace \& Co with whose help the cohort was identified and past exposures estimated. We received help from several agencies in the follow up period and in particular we acknowledge the invaluable contribution of $\mathrm{Mr}$ Earl Lovick in all aspects of the study.

\section{References}

${ }^{1}$ McDonald JC, Sébastien P, Armstrong B. Radiological survey of past and present vermiculite miners exposed to tremolite. $B r J$ Ind Med 1986;43:445-9.

${ }^{2}$ Sébastien P, Armstrong B, Case B, McDonald JC. Estimation of amphibole exposure from asbestos body and macrophage counts in sputum: a survey in vermiculite miners. Ann Occup Hyg (in press).

${ }^{3}$ Sébastien P, Green F, Case B, Harley R, McDonald AD, McDonald JC. Tremolite and chrysotile fibres in human lung. Ann Occup Hyg (in press).

${ }^{4}$ Ross M, Kuntze RA, Clifton RA. A definition for asbestos. In: Levadie B, ed. Definitions for asbestos and other health-related silicates. Philadelphia: ASTM, 1984:139-47.

5 McDonald JC. Mineral fibres and cancer. Ann Acad Med Singapore 1984;13:345-52.

${ }^{6}$ Royal Commission on matters of health and safety arising from the use of asbestos in Ontario. Report. Toronto: Queen's Printer for Ontario, 1984.

${ }^{7}$ Acheson ED, Gardner MJ. Asbestos: the control limit for asbestos. London: Health and Safety Commission, HMSO, 1983.

${ }^{8} \mathrm{~K}$ leinfeld M, Messite J, Kooyama K. Mortality experience in a group of asbestos workers. Arch Environ Health 1967;15:177-80.

${ }^{9}$ Brown DP, Dement JM, Wagoner JK. Mortality patterns among miners and millers occupationally exposed to asbestiform talc. In: Lemen R, Dement JM, eds. Dust and disease. Park Forest South, Illinois; Pathotox, 1979:317-24. 
${ }^{10}$ McDonald AD, McDonald JC, Pooley FD. Mineral content of lung in mesothelial tumours in North America. Ann Occup Hyg 1982;26:417-22.

${ }^{11}$ Pooley FD. An examination of the fibrous mineral content of asbestos in lung tissue from the Canadian chrysotile mining industry. Environ Research 1976;12:281-98.

${ }^{12}$ Rowlands N, Gibbs GW, McDonald AD. Asbestos fibres in the lungs of chrysotile miners and millers. A preliminary report. Ann Occup Hyg 1982;26:411-5.

${ }^{13}$ Churg A, Wiggs B, Depaoli L, Kampe B, Stevens B. Lung asbestos content in chrysotile workers with mesothelioma. Am Rev Respir Dis 1984;130:1042-5.

${ }^{14}$ Wagner JC, Chamberlain M, Brown RC, et al. Biological effects of tremolite. Br J Cancer 1982;45:352-60.

${ }^{15}$ Rousseaux JM, Rouxhet PG, Vielvoye LA, Herbillon AJ. The vermiculization of trioctahedral micas. The $\mathrm{K}$ level and its correlation with chemical composition. Clay Minerals 1973;10:1-16.

${ }^{16}$ Atkinson GR, Rose D, Thomas K, Jones D, Chatfield EJ, Going JE. Collection, analysis and characterization of vermiculite samples for fibre content and asbestos contamination. Washington DC: US Environmental Protection Agency, 1981. (Contract No 68-01-5915.)

${ }^{17}$ US Department of Labor. Asbestiform and/or fibrous minerals in mine, mills and quarries. Pittsburgh: Mine and Safety and Health Adminstration, 1980.

${ }^{18}$ Walton WH. The nature, hazards and assessment of occupational exposure to airborne asbestos dust: a review. Ann Occup Hyg 1982;25:117-247.
${ }^{19}$ Sébastien P, Gaudichet A, Billon-Galland MA, Janson X. Spectrométrie $\mathrm{X}$ par dispersion d'énergie en microscopie électronique à transmission: application à la caractérisation des fibres minérals. Journal de Microscopie et de Spectroscopie Electronique 1980;5:83-97.

${ }^{20}$ International Mineralogical Association. Nomenclature of amphiboles. Canadian Mineralogist 1978;16:501-20.

${ }^{21}$ Edwards GH, Lynch JR. The method used by the US Public Health Serivce for enumeration of asbestos dust on membrane filters. Ann Occup Hyg 1968;11:1-6.

${ }^{22}$ Corn M, Esmen NA. Work place exposure zones for classification of employee exposures to physical and chemical agents. Am Ind Hyg Assoc J 1979;40:47-57.

${ }^{23}$ Oldham PD. On estimating the arithmetic means of lognormallydistributed populations. Biometrics 1965;213:235-9.

${ }^{24}$ Monson R. Analysis of relative survival and proportional mortality. Computers and Biomedical Research 1974;7:325-32.

${ }^{25}$ Hanley J, Liddell FDK. Fitting relationships between exposure and standardized mortality ratios. J Occup Med 1985;27:555-60.

${ }^{26}$ Thomas DC. General relative risk models for survival time and matched case-control analysis. Biometrics 1981;37:673-86.

${ }^{27}$ Doll R, Peto J. Effects on health of exposure to asbestos. London: Health and Safety Commission, HMSO, 1985.

${ }^{28}$ Liddell FDK, Thomas D, Gibbs GW, McDonald JC. Fibre exposure and mortality from pneumoconiosis, respiratory and abdominal malignancies in chrysotile production in Quebec, 1926-75. Ann Acad Med Singapore 1984;13:340-4.

${ }^{29}$ Oakes D, McDonald JC. Restricted cohort study designs. Scand J Work Environ Health 1982;8:30-3.

\section{Destruction of manuscripts}

From 1 July 1985 articles submitted for publication will not be returned. Authors whose papers are rejected will be advised of the decision and the manuscripts will be kept under security for three months to deal with any inquiries and then destroyed. 